\title{
Aucamville
}

La Pigeonnière

\section{Guillaume Nègre}

\section{(2) OpenEdition \\ Journals}

Édition électronique

URL : http://journals.openedition.org/adlfi/10990

ISSN : 2114-0502

Éditeur

Ministère de la culture

Référence électronique

Guillaume Nègre, «Aucamville », ADLFI. Archéologie de la France - Informations [En ligne], Midi-Pyrénées, mis en ligne le 01 mars 1997, consulté le 24 avril 2019. URL : http://journals.openedition.org/ adlfi/10990

Ce document a été généré automatiquement le 24 avril 2019.

(C) Ministère de la Culture et de la Communication, CNRS 


\title{
Aucamville
}

\author{
La Pigeonnière
}

\section{Guillaume Nègre}

Date de l'opération : 1989 (DF)

Inventeur(s) : Nègre G

1 A l'occasion de labours profonds, G. Nègre a pu redécouvrir et délimiter avec précision un site signalé de façon imprécise dans la monographie communale publiée en 1890. Les découvertes de surface évoquent un établissement rural dont l'origine remonte au moins au II $\mathrm{s}$. de notre ère, mais dont l'occupation s'est prolongée jusqu'au IV $s$.

\section{INDEX}

Index chronologique : Empire romain

Index géographique : Midi-Pyrénées, Tarn-et-Garonne (82), Aucamville

operation Découverte fortuite (DF) 